\title{
Comparative Study of Carvones from Various Essential Oils and Their Ability to Increase the Stability of Fat-Containing Products
}

\author{
Nataliia Frolova', Nataliia Yushchenko', Olga Korablova², \\ Volodymyr Voitsekhivskyi ${ }^{3}$, Alona Ocheretna', Tetiana Synenko ${ }^{4}$ \\ 1 National University of Food Technologies, Volodymyrska str., 68, 01601 Kyiv, Ukraine \\ 2 National Botanical Garden of NAS of Ukraine, Timiryazevska Str., 1, 01014 Kyiv, Ukraine \\ ${ }^{3}$ National Universities of Life and Environmental Sciences of Ukraine, Heroyiv Oborony Str. 15, 03041 Kyiv, \\ Ukraine \\ ${ }^{4}$ Sumy National Agrarian University, G. Kondratieva Str. 160, 40000 Sumy, Ukraine \\ * Corresponding author's email: okorablova@ukr.net
}

\begin{abstract}
Carvone is a key component of essential oils from the Anethum graveolens L. (dill) and Mentha spicata L. (mint) plants. It was obtained in pure form by preparative isolation from the Mentha spicata essential oils. It has been established that essential oils contain carvone in various optically active forms. The essential oil of dill contains $d$-(R)-carvone (right-rotating isomer form) with a specific rotation of the plane of polarization $[\alpha] D+62.5+0.05$; mint essential oil from Mentha spicata contains $l$-(S)-carvone (left-rotating isomer form) with a specific rotation of the plane of polarization $[\alpha] D-63.2+0.05$. An organoleptic analysis reliably determined the aromatic characteristics of carvone: $(S)$-carvone of dill essential oil has a spicy aroma of fresh dill, in turn $(R)$-carvone of mint essential oil from Mentha spicata - has the aroma of cumin with menthol tones. The research of the method of accelerated oxidation proved that the introduction of antioxidants in the form of optical isomers into sunflower oil leads to an increase in the concentration of fat-containing products by 2.4-3.0 times by the values of peroxide number and 1.5-1.7 times by the values of acid number, in comparison with control. Comparing the effect of carvone optical isomers among themselves by the oxidation dynamics of fat-containing products, it was found that in general their protection effect is similar. However, the leftward carvone shows a higher effect on the resistance of sunflower oil as compared with the rightward carvone. Except for the protection from oxidation, the optical isomers of carvone can have a physiological effect on a human body. Thus, the optical isomers of carvone can add certain aromas to foodstuffs, and when functional fat-containing products are created, it is possible to use both optical forms of carvone, depending on the orientation of a new functional product.
\end{abstract}

Keywords: essential oils; preparative isolation; carvone isomers; oxidation processes; natural anti-oxidants

\section{INTRODUCTION}

One of the crucial factors for the improvement of people's health is the rationalization of nutrition. The unbalanced food ration, along with some ecological problems becomes the reason for serious disorders in the functioning of a human body. The appearance of these disorders depends greatly on food quality, the contents of essential substances in it, safety as well as its chemical composition. Vegetable oils belong to the most widely used products of the everyday food ration.
They comprise essential fat-containing acids, which is why they have to be regularly consumed with food. Vegetable oils are the main source of natural plant sterols in the diet and contain minor components, such as squalene and sphingolipids, all of which may provide a range of health benefits [Félix et al. 2020].

Culinary oils and the products made from them, such as fat spreads, have a role in a healthy, balanced diet, even though they are energy dense and contain a high proportion of fat. They are particularly important sources of vitamins $D$ and $E$ 
in the diet, as well as contribute to the vitamin $A$ intake [Foster, Williamson and Lunn 2009; Frolova et al. 2019].

A limited consumption of these products disrupts the metabolism processes, which in turn causes various diseases. Suppression of the immune system and damage of cell structures come first. Oils belong to perishable products, in particular those which comprise the essential fat-containing acids of the $\omega-6$ and $\omega-3$ family. A continuous process of their oxidation takes place during storage and simultaneously harmful and toxic compounds grow [Tolba et al. 2017]. Prevention of fat spoilage requires controlling their oxidation degree and slowing down this process by adding antioxidants. However, despite the paramount need for preservatives, specifically for food products, the use of synthetic antioxidants as additives in product formulas has been increasingly discouraged by policy makers and consumers, given their proven/ potential negative effects on the human health and the environment [Nahas 2012].

The Anethum graveolens plants and essential oil from them had many benefits for healthcare and it could be used in some parts of the world as food additives [Badr et al. 2008]. The essential oil and different extracts of the Anethum graveolens seeds exerted antimicrobial activity against a wide range of microorganisms [Altameme, Hameed and Hamza 2017]. It has to be stated that lipophilic anti-oxidants of a plant origin, including volatile oils and their components, are rarely used in updated technologies. However, the use of synthetic antioxidants in the food industry has raised important questions about the effects of prolonged consumption on human health [Munekata et al. 2020; Lorenzo et al. 2017].

The research of domestic and foreign scientists proves that the addition of volatile oils increases the period of the safe storage of a fat-containing produce (Samusenko, 2011; Foda et al., 2010). They, even in small amounts, are effective natural antioxidants, capable of competing with strong synthetic counterparts [Gupta 2002].

The antioxidant effect is produced by essential oils of dog-rose, carnation, mint, lemon, coriander and Echinacea [Modzelewska et al. 2005]. The essential oils of laurel and cardamom are very much similar in terms of the component composition, but laurel oil is 1.5 times more efficient antioxidant than cardamom oil [Ponomareva 2015].

The antioxidant activity of essential oils depends on the availability of phenolic compounds and their derivatives in their component composition [Dunning 2013]. The mixture of lemon, coriander and carnation has the highest anti-oxidant activity. They have a strong anti-oxidant in their component composition $-\gamma$-terpinen [Misharina 2010; Franz 2010]. The essential oil of carnation is an active anti-oxidant due to eugenol [Syzova 2010]. Essential oils, which contain thymol, carvacrol, have strong anti-oxidant properties [Dima and Dima 2015].

Mentha spicata L. originates from the Mediterranean, but has been introduced and grown in many countries around the world, including Ukraine [Korablova and Rakhmetov 2012]. Its essential oil is effectively used as a strong antioxidant for nutraceuticals and for cosmetic products [Rabotyagov et al., 2011]. A key component of this essential oil is carvone, which is also available in large amounts in dill and cumin essential oils [Kondratyuk 2013].

Carvone belongs to a terpene class which is widely common in nature [Babushkina 2009]. In 1894, the carvone structure was determined by G. Wagner [1984]. A carvone molecule exists in two isomers: $S-(+)$-carvone and $R-(-)$-carvone. The chemical formulas of optically active isomers of carvone are presented in Figure 1.

Isomers: $S-(+)$-carvone and $R$-(-)-carvone are characterized with similar physical-chemical properties (boiling temperature $\mathrm{t}_{\text {boil }}-230^{\circ} \mathrm{C}$; relative density $d_{4}^{20}$ at temperature $20^{\circ} \mathrm{C}-0.9611$; refraction indicators $n_{D}{ }^{20}-1.499$ ), but they differ in the interaction of optically active reagents [Bacherikov 2011].

The optical isomers of carvone have different effects on human body. For instance, $(R)$-carvone inhalation causes the increased heart rate and blood pressure. Thus, the leftward form of carvone has an effect on a central nervous system and stimulates the brain work. The effect of $(S)$ carvone, i.e. a rightward form, stimulates the gastrointestinal tract [Lawrence et al. 2009].
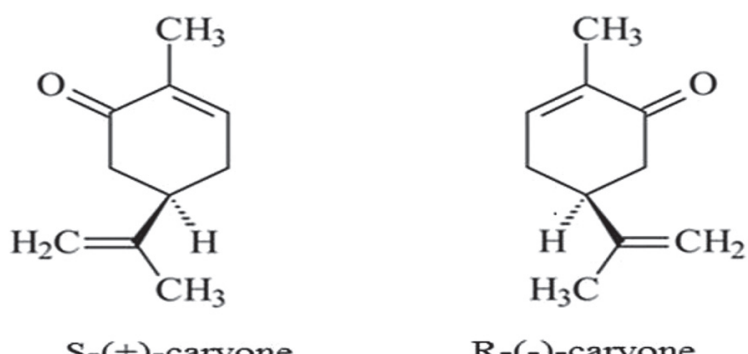

$-(+)$-carvone

R-(-)-carvone

Figure 1. Optically active isomers of carvone 
The world experience proves that the aroma nature of aromatic components depends to a great extent on the optical activity [Evlash and Kuznetsova 2015; Frasnelli et al. 2015].

Optical isomerism plays an important role in the technologies of essential oil processing, as enantiomers of one substance usually differ by aroma tonality and its strength among themselves. For instance, the (S)-carvone smells like dill, whereas the $R$-carvone has cumin aroma. Carvone can be extracted from natural essential oils; however, nowadays an organic and biotechnological synthesis with available limonene is used more frequently [Klyuchnik et al. 2009]. The purpose of the research work was to study optical carvone isomers extracted from the essential oils of dill (Anethum graveolens L.) and mint (Mentha spicata L.), as anti-oxidants which can increase the stability of plant oils.

\section{MATERIALS AND METHODS}

The research was carried out at the National University of Food Technologies in Kyiv. The Anethum graveolens and Mentha spicata plants were grown in M. M. Gryshko National Botanical Garden (NBG) of NAS of Ukraine (Fig. 2).

The essential oils of dill (Anethum graveolens L.) and mint (Mentha spicata L.), as well as carvone optical isomers after preparative extraction from chosen essential oils, were used as source of the substances with an antioxidant effect (antioxidants). The essential oils from the flowering parts of mint and dill were obtained by using the water distillation procedure for $2 \mathrm{~h}$ using Clevenger type apparatus, according to the method described by El-Seedi et al. [2008]. The physical-chemical indicators of essential oils were determined with the help of the standardized techniques generally accepted in Ukraine.

The gas-chromatographic analysis of essential oils, individual carvones was performed on a Hewlett-Packard 5890/II chromatograph with a quadruple mass spectrometer (HP/MSD 5971 using the Frolova methodology [2014]. The organoleptic indicators of the optical isomers of carvone were determined according to SStU 2719-94 (State Standard of Ukraine) at room temperature $20 \pm 5^{\circ} \mathrm{C}$.

A preparative column was applied in which a granularity gradient degree of a firm carrier of Chromosorb A of the "Johns Manville" company (the USA) was used, as well as a gradient decrease of the concentration of a stationary PEG 6000 phase along a column, beginning with a sample introduction. Preparative separation was done by the following parameters: a stationary phase - PEG 6000, an evaporator temperature $200^{\circ} \mathrm{C}$, a component catcher temperature $-10^{\circ} \mathrm{C}$, a gas-carrier speed $-90 \mathrm{~cm}^{3} / \mathrm{min}$. A value of the isomer optical activity was determined by using a polarimetric method, when: $20^{\circ} \mathrm{C}$, a wave length of $D$ line of sodium spectrum (589.3 nm). Optical purity $(o p)$ was calculated with formula 1 :
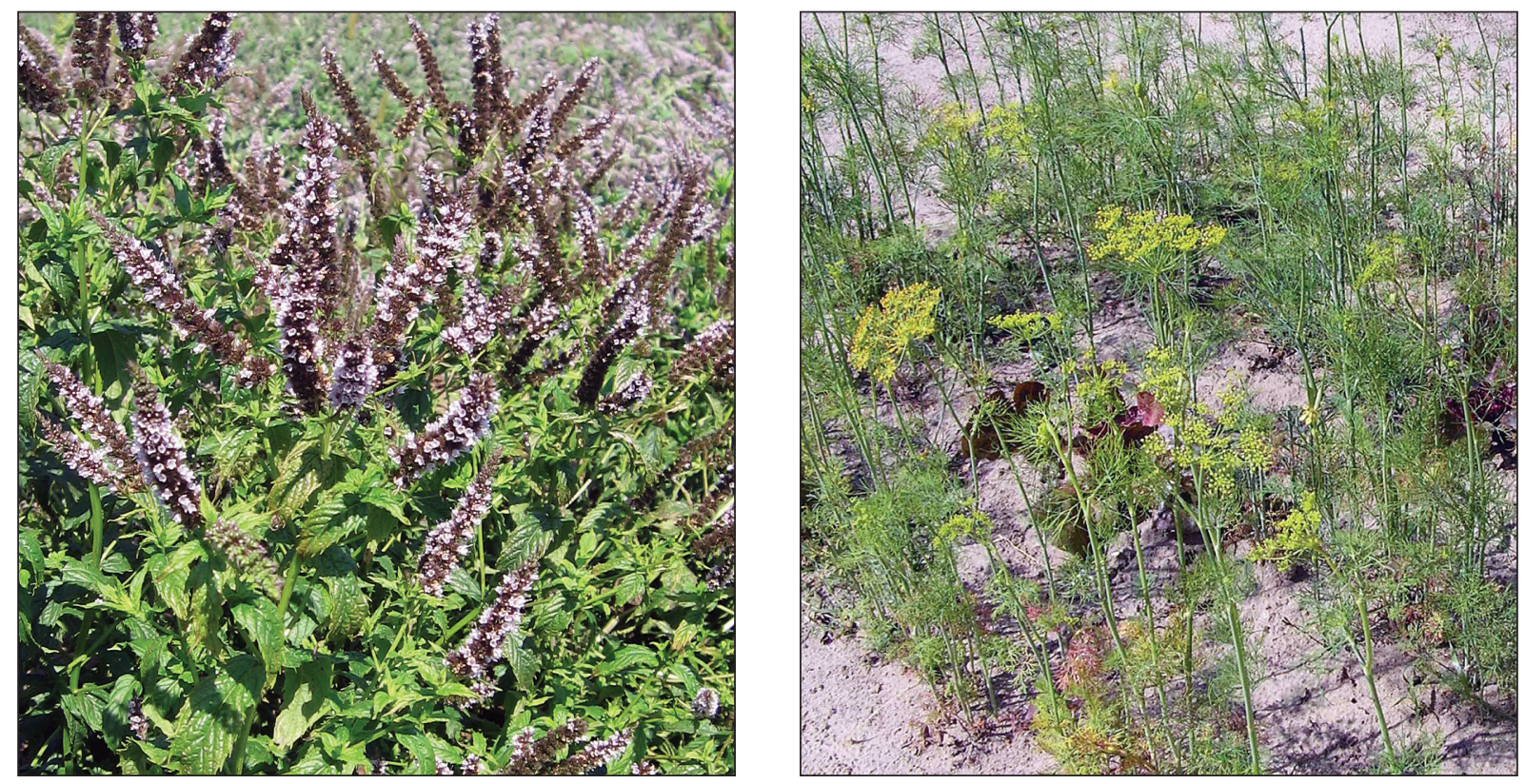

Figure 2. The Mentha spicata (A) and Anethum graveolens plants (B) 


$$
o p=[\alpha] \text { research } /[\alpha] \text { stand, }
$$

where: $[\alpha]$ research - specific rotation of the polarization area for the test substance;

$[\alpha]$ stand - a maximal (absolute) specific rotation of the plane of polarization of light for enantiomeric pure sample.

The optical activity of carvones, extracted from different essential oils, was determined by the ability to rotate a light polarization plane into certain angles under the defined conditions. The enantiomeric (optical) purity was calculated in \% which confirmed the quantity of the main enantiomer in the sample.

The accelerated method was used to study the dynamics of oxidation, exposing model samples in a thermostat at temperatures $93 \pm 2^{\circ} \mathrm{C}$ during a chosen amount of time. In order to obtain model samples, lipophilic components were mixed, namely plant oil and $0.1 \%$ anti-oxidants - essential oils and carvone samples, extracted from them. The dynamics of oxidation was controlled by the change in the values of a peroxide number $(P N)$ and an acid number $(A N)$ during 60 minutes. The values of $P N$ and $A N$ were measured every 20 minutes. Nonrefined sunflower oil "Shchedryi dar" was used in the trials; initial values of $A N$ were $0.22 \pm 0.05 \mathrm{mg}$ $\mathrm{KOH} / \mathrm{g}$, those of $P N-5.2 \pm 0.3 \mathrm{mmol} 1 \frac{1}{2} \mathrm{O} / \mathrm{kg}$. The time during which $P N$ reaches $10 \mathrm{mmol} 1 / 2 \mathrm{O} / \mathrm{kg}$ is the guaranteed shelf life of the sunflower oil according to the State Standard of Ukraine [SStU ISO 6886-2003]. The extraction of carvone fractions from the studied essential oils was done with a homemade method according to the technique of a preparative extraction of individual components of essential oils [Frolova 2013].

\section{RESULTS AND DISCUSSION}

The physical-chemical indicators of the chosen essential oils were checked as to how they met the requirements of State Standard of Ukraine. Results of investigations are presented in Table 1 and 2.

A comparative analysis of normative and studied indicators of the chosen essential oils showed that in terms of the physical-chemical indicators, dill and mint essential oils fully met the requirements of the normative-technical documentation, which made it possible to use them in further research.

Chromatograms of dill and mint essential oils are presented in Figure 3. The percentage of key components was determined on chromatograms and presented in Table 3.

Natural flavors may have higher minimum effective concentrations than their synthetic counterparts, but they will offer increased consumer acceptability, decreased potential health risks, and can often achieve the same degree of oxidation prevention [Oswell, Thippareddi and Pegg 2018]. These data are consistent with our research. Table 4 shows the content of the key components of the Mentha spicata essential oil.

It is obvious that the studied essential oils contain a key component - carvone - in a dominant amount: dill oil $-49.52 \%$, mint oil $-73.03 \%$. In order to effectively extract carvone from essential oils, the effect of a thermostat column temperature on a coefficient of the separation of carvone and the components with a close boiling temperature (critical pairs) - mentone and dihydrocarvone - was studied. A thermostat column temperature $\left(\mathrm{T}_{\text {col. }}\right)$ was changed from 140 to $170^{\circ} \mathrm{C}$

Table 1. Physical and chemical indices of the Anethum graveolens essential oil

\begin{tabular}{|l|c|c|}
\hline \multicolumn{1}{|c|}{ Indicator } & SStU 4653:2006 & Research \\
\hline Relative density at $20^{\circ} \mathrm{C},\left\ulcorner/ \mathrm{cm}^{3}\left(\mathrm{~d}_{4}{ }^{20}\right)\right.$ & $0.870-0.920$ & $0.907 \pm 0.001$ \\
\hline Refractive index at $20^{\circ} \mathrm{C}\left(\mathrm{n}_{\mathrm{D}}{ }^{20}\right)$ & $1.481-1.490$ & $1.482 \pm 0.001$ \\
\hline Optical activity, deg. $\left(\alpha_{\mathrm{D}}\right)$ & from +60 to +90 & $+63 \pm 1$ \\
\hline Acid number, $\mathrm{mg} \mathrm{KOH}$, no more & no more 1 & 1.00 \\
\hline Solubility of 1 volume oil in $70 \%$ ethanol solution & in 6 volumes & corresponds \\
\hline
\end{tabular}

Table 2. Physical and chemical indices of the Mentha spicata essential oil

\begin{tabular}{|l|c|c|}
\hline \multicolumn{1}{|c|}{ Indicator } & SStU ISO 3033-2002 & Research \\
\hline Relative density at $20^{\circ} \mathrm{C}, \mathrm{g} / \mathrm{cm}^{3}\left(\mathrm{~d}_{4}{ }^{20}\right)$ & $0.920-0.937$ & $0.926 \pm 0.001$ \\
\hline Refractive index at $20^{\circ} \mathrm{C}\left(\mathrm{n}_{\mathrm{D}}{ }^{20}\right)$ & $1.485-1.491$ & $1.485 \pm 0.001$ \\
\hline Optical activity, deg. $\left(\alpha_{\mathrm{D}}\right)$ & from -60 to -45 & $-55 \pm 1$ \\
\hline Acid number, $\mathrm{mg} \mathrm{KOH}$, no more & no more 1 & 0.50 \\
\hline Solubility of 1 volume oil in $80 \%$ ethanol solution & in 20 volumes & corresponds \\
\hline
\end{tabular}



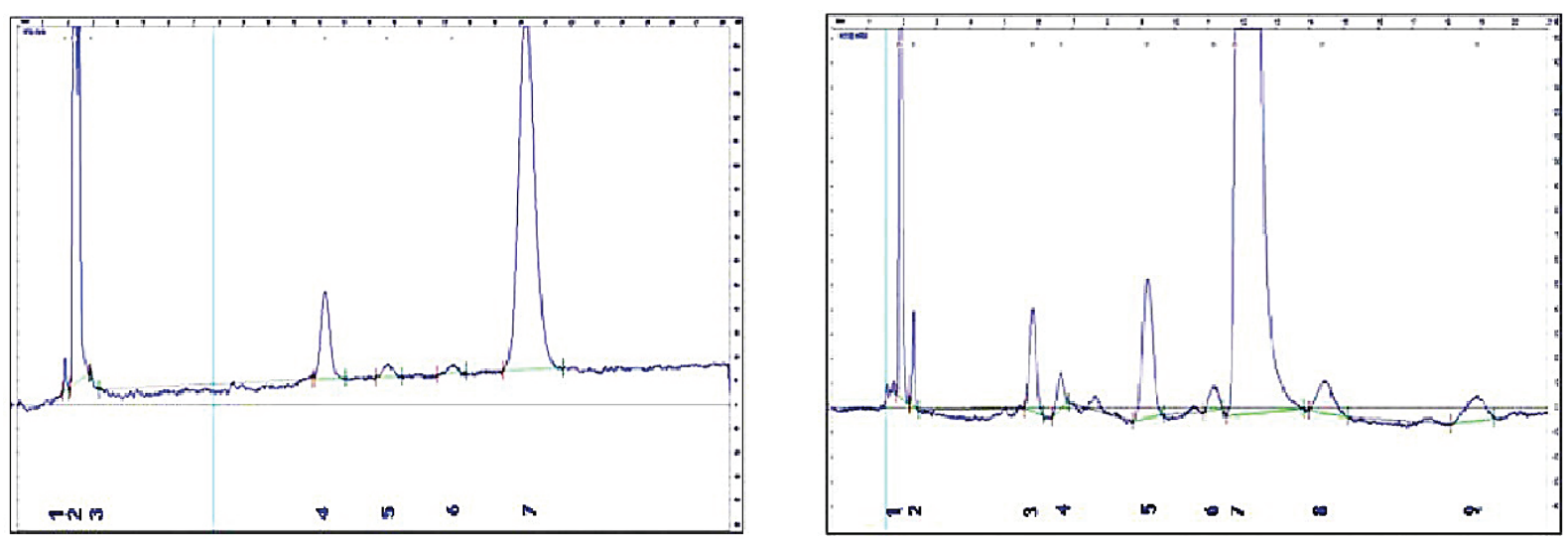

Figure 3. Chromatograms of Anethum graveolens (left) and Mentha spicata essential oils (right)

Table 3. Content of the key components of dill essential oil

\begin{tabular}{|c|c|c|c|}
\hline № peak on the chromatogram & $t$, minutes & $S, \%$ & Substance \\
\hline 1 & 1.89 & 0.82 & - \\
\hline 2 & 2.23 & 36.66 & limonene \\
\hline 3 & 3.06 & 0.35 & - \\
\hline 4 & 12.23 & 10.05 & - \\
\hline 5 & 14.70 & 1.62 & - \\
\hline 6 & 17.28 & 1.05 & carvone \\
\hline 7 & 20.23 & 49.52 & \\
\hline
\end{tabular}

Note: $t$ - time of retention, $S$ - content of the components.

Table 4. Content of the key components of the mint essential oil, $\%$

\begin{tabular}{|c|c|c|c|}
\hline № peak on the chromatogram & $t$, minutes & $S, \%$ & Substance \\
\hline 1 & 1.96 & 12.99 & limonene \\
\hline 2 & 2.36 & 0.93 & - \\
\hline 3 & 5.86 & 2.63 & - \\
\hline 4 & 6.67 & 0.93 & - \\
\hline 5 & 9.21 & 5.12 & - \\
\hline 6 & 11.19 & 0.74 & carvone \\
\hline 7 & 12.05 & 73.03 & - \\
\hline 8 & 14.43 & 1.88 & - \\
\hline 9 & 18.93 & 1.76 & - \\
\hline
\end{tabular}

Note: $t$ - time of retention, $S$ - content of the components.

with a step equal to $10^{\circ} \mathrm{C}$. Times of retention are presents in Table 5. The table shows that as the temperature increases the time of keeping components decreases. The width of peaks $\omega$ and the distance between critical pairs $d$ were measured; it helped calculate their separation coefficients $R$ [Gindullina and Dubova 2010]. If $R=1,98 \%$ of the total separation of a critical pair is obtained (Table 6). The obtained dependences are depicted in the form of a diagram in Figure 4, which makes it possible to determine the temperature optimum of carvone selection.
On the basis of the presented data, it has been found out that a separation coefficient of mentone-carvone $(R m-c=1.58)$ reaches its maximum at $160^{\circ} \mathrm{C}$, and a separation coefficient of carvonedihydrocarvone does not respond to a temperature change. Such variation is explained by a molecule structure of the components and close boiling temperatures. Thus, the temperature of a preparative column thermostat was chosen $-160^{\circ} \mathrm{C}$.

A preparative separation of the essential oil samples allowed the accumulation of carvone fraction in the amounts which were enough to 
Table 5. Time of retention for component in the preparation column

\begin{tabular}{|c|c|c|c|}
\hline \multirow{2}{*}{$T_{\text {col. }}{ }^{\circ} \mathrm{C}$} & \multicolumn{2}{|c|}{ Time of retention for component, minutes } \\
\cline { 2 - 4 } & mentone & carvone & dihydrocarvone \\
\hline 140 & $19.33 \pm 0.02$ & $31.67 \pm 0.04$ & $37.50 \pm 0.02$ \\
\hline 150 & $18.67 \pm 0.01$ & $30.83 \pm 0.02$ & $36.83 \pm 0.03$ \\
\hline 160 & $18.00 \pm 0.02$ & $30.17 \pm 0.02$ & $36.50 \pm 0.04$ \\
\hline 170 & $17.50 \pm 0.01$ & $29.50 \pm 0.01$ & $35.83 \pm 0.02$ \\
\hline
\end{tabular}

Table 6. Coefficients of partition components of critical pairs

\begin{tabular}{|c|c|c|}
\hline \multirow{2}{*}{$T_{\text {col. }}{ }^{\circ} \mathrm{C}$} & \multicolumn{2}{|c|}{ Coefficients of partition of critical pairs } \\
\cline { 2 - 3 } & mentone - carvone $(R m-c)$ & carvone - dihydrocarvone $(R c-d)$ \\
\hline 140 & 0.93 & 0.47 \\
\hline 150 & 1.00 & 0.48 \\
\hline 160 & 1.58 & 0.48 \\
\hline 170 & 1.59 & 0.48 \\
\hline
\end{tabular}

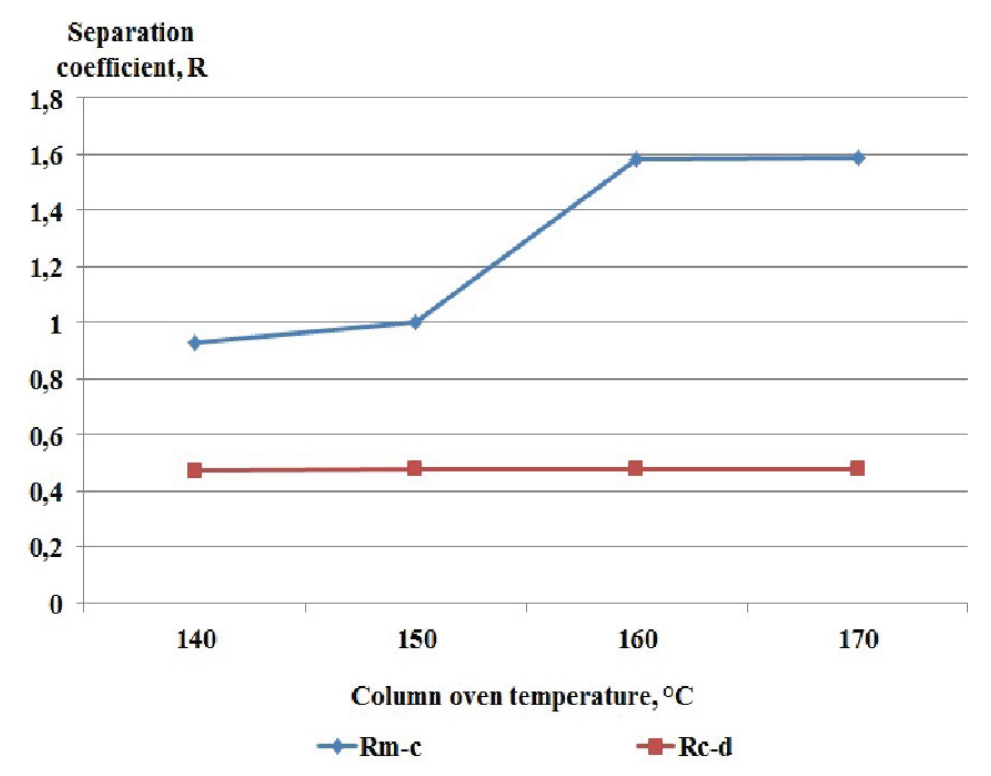

Figure 4. Value of $R$ components of critical pairs at different temperatures

carry out the planned research. The fraction collection for all trial series was $82.5-89.0 \%$. The chromatograms of carvone fraction from essential oils of dill and mint are presented in Figure 5.

The essential oil and extracts of dill plant possess promising antibacterial, antifungal, antioxidant, insecticidal, anti-inflammatory, antidiabetic, antispasmodic, hypolipidemic activities etc. [Chahal et al. 2017]. According to the results of the chromatogram calculation, the carvone fraction from dill essential oil was $99.3 \%$ and that of mint essential oil - 99.1\%, which was a degree of individual carvone purity. The results are presented in Table 7.

Essential oils and carvone isomers were studied as anti-oxidants with the ability to increase the resistance of fat-containing products. The research results were shown in figures of the dynamics of $P N$ and $A N$ values in the model samples when dill essential oil was introduced into a fat base in the amount of $0.1 \%$ (Fig. 6).

Apparently, the increase of the $P N$ value (the well-guaranteed $P N$ value was $10 \mathrm{mmol} 1 / 2 \mathrm{O} /$ $\mathrm{kg})$ slowed down by $75 \pm 2 \%$. The $A N$ value decreased by $50 \pm 2 \%$ as compared with sunflower oil without essential oil. The dynamics of the $P N$ and $A N$ values in the model samples with mint essential oil (concentration of essential oil $-0.1 \%$ ) were presented in Figure 7. It is obvious that the introduction of $0.1 \%$ of mint essential oil slows down the oxidation speed of sunflower oil (as to $P N$ value $10 \mathrm{mmol}^{1 /} \mathrm{O} / \mathrm{kg}$ ) by 1.88 times. The $A N$ value decreases by 1.84 times. 


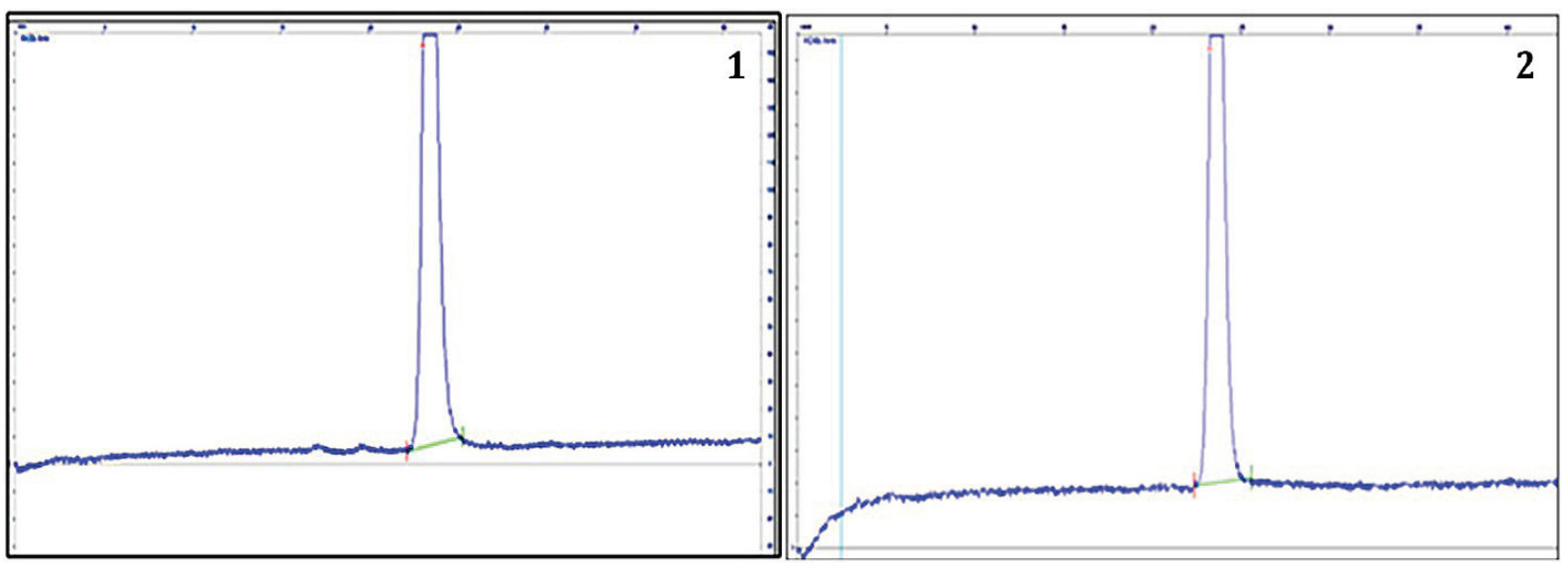

Figure 5. Chromatograms of carvone fractions from experimental essential oils: 1 - dill essential oil; 2 - mint essential oil
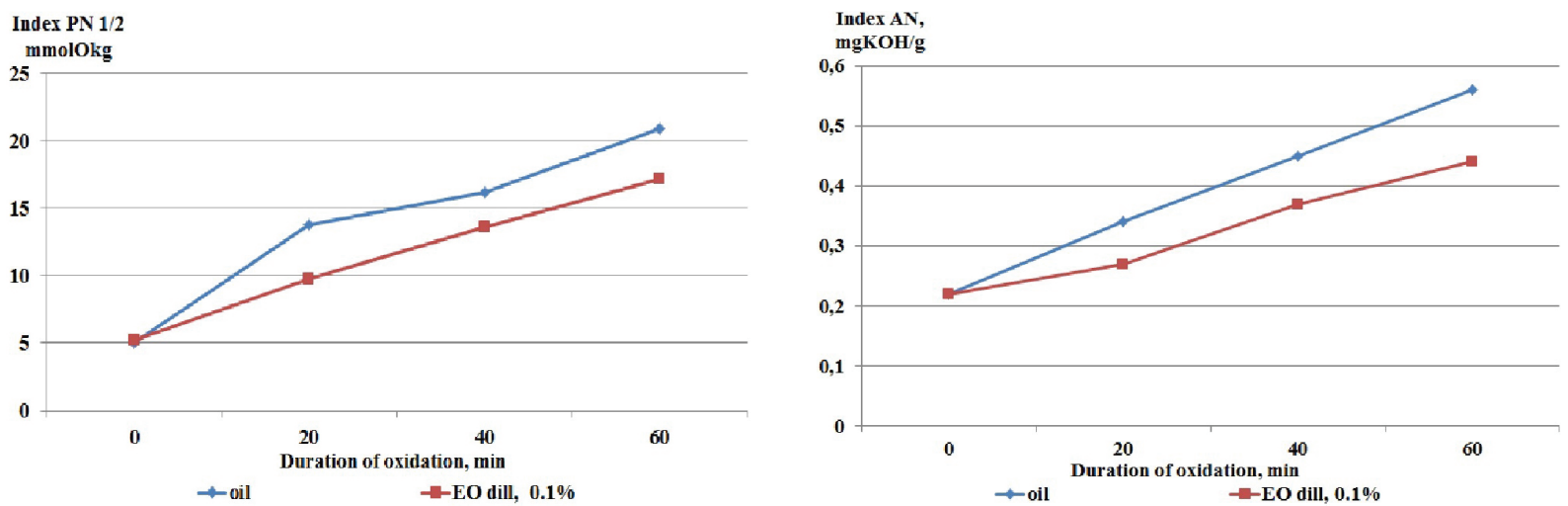

Figure 6. Effect the duration of oxidation at the concentration of dill essential oil $0.1 \%$ on the values of $P N$ and $A N$ of oils

Table 7. Optical activity of carvones from experimental essential oils

\begin{tabular}{|c|c|c|c|}
\hline \multirow{2}{*}{ Essential oil } & \multicolumn{2}{|c|}{ Specific rotation of the plane of polarization } & \multirow{2}{*}{$\begin{array}{c}\text { Optical } \\
\text { (enantiomeric) purity }\end{array}$} \\
\cline { 2 - 3 } & standard & research & $100 \%$ \\
\hline $\begin{array}{c}\text { Dill }-d \text {-(R)-carvone } \\
\text { (right rotational form) }\end{array}$ & +61 & {$[\alpha] D+62.5+0.05$} & $99.6 \%$ \\
\hline $\begin{array}{c}\text { Mint }- \text { I-(S)-carvone, } \\
\text { (left rotational form) }\end{array}$ & -62 & {$[\alpha] D-63.2+0.05$} & 9 \\
\hline
\end{tabular}

The $P N$ dynamics in the model samples with different optical isomers of carvone were presented in Figure 8. The concentration of carvone optical isomers was $0.1 \%$. A control sample was oil without anti-oxidants. The research carried out with help of a method of accelerated oxidation showed that when anti-oxidants in the form of carvone optical isomers in concentration $0.1 \%$ were introduced into sunflower oil, the speed of reaching a critical $P N$ value -10 mmol 1/2 O/kg - was slowed down by 3 times. The value of $A N$ was slowed down by 1.5 times, as compared with the control. The resistance to product oxidation increased by 1.5-3.0 times.
As the concentration of carvones increased by $0.5 \%$, their ability to protect fat-containing products from oxidation increased by 8.0 $\pm 0.5 \%$. An optimal number of carvone isomers $-0.1 \%$ - were determined in other series of the trials. Comparing the effect of carvone optical isomers among themselves by the oxidation dynamics of the initial oil, it was found out that the leftward carvone shows a more intensive effect on its resistance as compared with the rightward carvone (the difference is $\pm 11.4 \%)$.

According to the results of Tolba et al. [2008], the extracts of dill essential oils exhibited the 

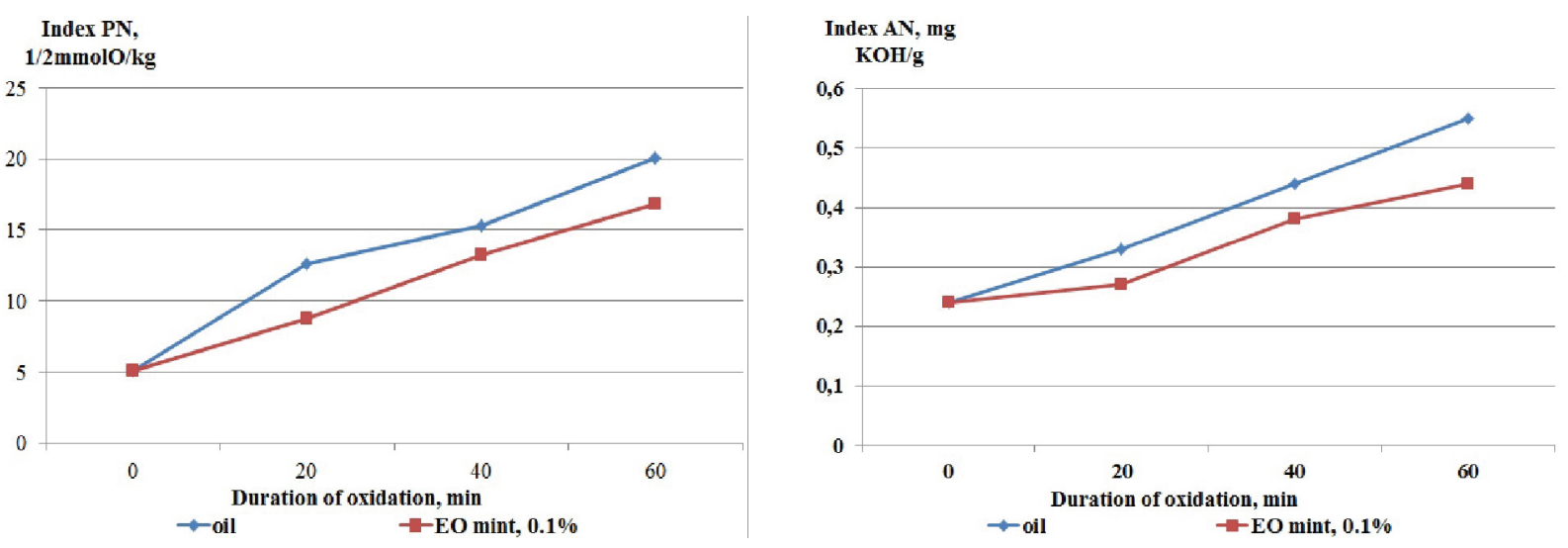

Figure 7. Dynamics of the $P N$ and $A N$ values in the model samples mint essential oil

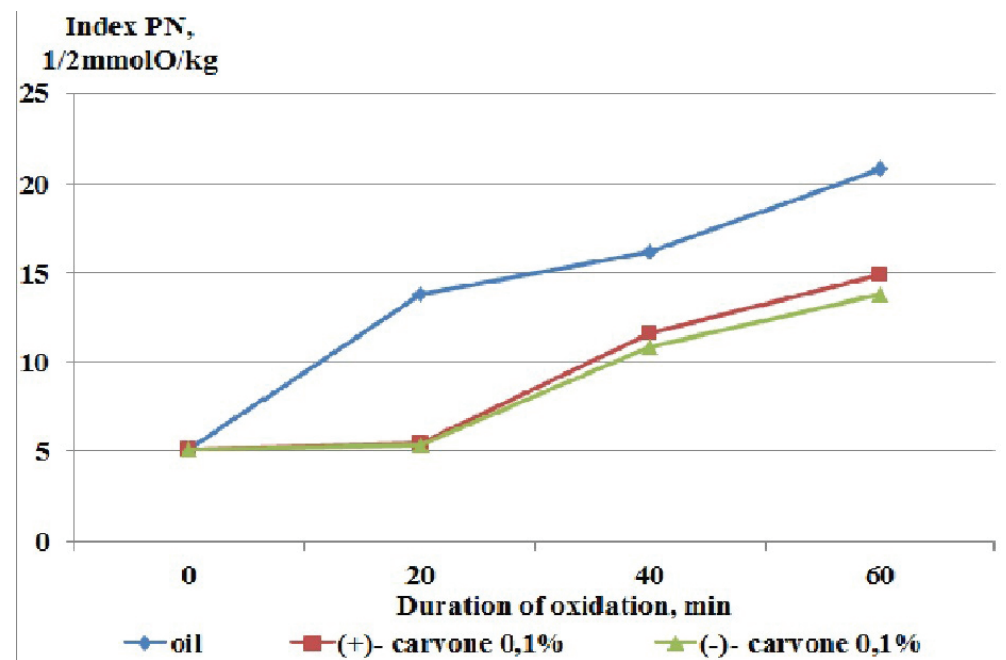

Figure 8. Dynamics of the values $P N$ in model samples with different optical isomers carvone

antimicrobial activity which caused inhibition of the microorganism's growth; also using these extracted essential oils as antioxidant improved the sunflower oil stability, achieved nutritional and economical gain.

The carried out research confirmed the availability of carvone enantiomers of an optical row with a high level of enantiomeric (optical) purity in a dill essential oil. $l-(S)$-carvone enantiomer was found in a mint essential oil.

The conducted research also proved the difference in the aromatic properties of carvones of various essential oils: the dill carvone has an aroma of fresh dill; in turn, the mint carvone has a cumin aroma with well-expressed menthol scents. The diversity of carvone aroma is due to a multidirectional optical activity.

However, not all essential oils have this property. First of all, it is connected with a component composition of essential oil and the property of its key components.
It was found that the protection effects of the optical isomers of carvone on the oxidation dynamics of fat-containing products in general are similar. However, the leftward carvone shows a higher effect on the resistance of sunflower oil as compared with the rightward carvone. Except for the protection from oxidation, the optical isomers of carvone can have a physiological effect on a human body. Thus, when functional fat-containing products are created, it is possible to use both carvone optical forms, depending on the orientation of a new functional product.

\section{CONCLUSIONS}

The conducted research proved the efficiency of preparative gas-chromatography for the extraction of key components of essential oils in a pure form and their further use, including the determination of essential oil authenticity. 
Three tasks can be solved when essential oils and separated key components are introduced into fat-containing products, namely: the increase of their resistance to oxidant spoilage, the aromatization of a fat-containing product and the improvement of a biological value due to the introduction of biologically active compounds with various physiological effects.

Enriched sunflower oil can be used as dressing for vegetable salads or can be part of recipes of fat-containing products, increasing their resistance and adding biological value to them. The optical isomers of carvone can add certain aromas to foodstuffs; therefore, it is possible to use both optical forms of carvone for new fatcontaining functional products, depending on their aroma orientation.

\section{REFERENCES}

1. Altameme H.J., Hameed I.H. and Hamza L.F. 2017. Anethum graveolens: Physicochemical Properties, Medicinal Uses, Antimicrobial Effects, Antioxidant Effect, Anti-Inflammatory and Analgesic Effects: A Review. International journal of pharmaceutical quality assurance, 8 (3), 88-91. https://www. researchgate.net/publication/320082200

2. Babushkina A.V. 2009. Optically pure compounds are the key to the future. Ukrainian Medical Journal, 5, 73. URL: https://www.umj.com.ua/wp/wp-content/uploads/archive/73/pdf/1510_rus.pdf?upload= (In Russian).

3. Bacherikov V.A. 2011. Carvone. Scientific bulletin of the international humanities university, 2, 62-66. URL: http://nbuv.gov.ua/UJRN/Nvmgu_ medf 2011213 (in Ukrainian).

4. Badr A.N., Nada F., Shehata M.G. and Amra H.A. 2017. Anti-mycotic and anti-mycotoxigenic properties of Egyptian Dill. Journal of Applied Sciences, 17, 184-195. DOI: 10.3923/jas.2017.184.195

5. Chahal K.K., Monika A.K., Kumar A., Bhardwaj U. and Kaur R. 2017. Chemistry and biological activities of Anethum graveolens L. (dill) essential oil: A review. Journal of Pharmacognosy and Phytochemistry, 6 (2), 295-306. https://www.phytojournal.com/ archives/2017/vol6issue2/PartF/6-2-67-817.pdf

6. Dima C. and Dima S. 2015. Essential oils in foods: extraction, stabilization, and toxicity. Current Opinion in Food Science, 5, 29-35. DOI: 10.1016/j. cofs.2015.07.003

7. Dunning T. 2013. Aromatherapy: overview, safety and quality issues. OA Alternative Med, 1 (1), 1-6. URL: http://www.oapublishinglondon.com/images/ article/pdf/1393742229.pdf
8. El-Seedi, H.R., Khattab, A., Gaara, A.H.M., Mohamed, T.K., Hassan, N.A., and El-kattan, A.E. 2008. Essential oil analysis of Micromeria nubigena H.B.K. and its antimicrobial activity. Journal of Essential Oil Research, 20 (5), 452-456. https://doi. org/10.1080/10412905.2008.9700057

9. Evlash V.V., Kuznetsova T.O. 2015. Chemistry of aroma-forming substances. Teaching manual / electron. data. Kharkiv : KhDUHT (in Ukrainian).

10. Félix R., Valentão P., Andrade P.B., Félix C., Novais S.C. and Lemos M.F.L. 2020. Evaluating the In Vitro Potential of Natural Extracts to Protect Lipids from Oxidative Damage. Antioxidants, 9 (3), 231-260. https://doi.org/10.3390/antiox9030231

11. Foda M.I., El-Sayed M.A., Hassan A.A., Rasmy N.M. and El-Moghazy M.M. 2010. Effect of Spearmint Essential Oil on Chemical Composition and Sensory Properties of White Cheese. Journal of American Science, 6 (5), 272-279.

12. Foster R., Williamson C.S. and Lunn J. Culinary oils and their health effects. 2009. British Nutrition Foundation Nutrition Bulletin, 34, 4-47. URL: https://www.nutrition.org.uk/attachments/113_Culinary $\% 20$ oils $\% 20$ and $\% 20$ their $\% 20$ health $\% 20$ effects.pdf

13. Franz C.M. 2010. Essential oil research: past, present and future. Flavour and fragrance journal, 25 (3), 112-118. https://doi.org/10.1002/ffj.1983

14. Frasnelli J., Hummel C., Bojanowski V., Warr J., Gerber J. and Humme T. 2015. Food-related odors and the reward circuit: Functional MRI. Chemosensory perception, 8 (4), 192-200. https://doi. org/10.1007/s12078-015-9193-8

15. Frolova N., Uktainets A., Korablova O. and Voitsekhivskyi V. 2019. Plants of Nepeta cataria var citriodora Beck. and essential oils from them for food industry. Potravinarstvo Slovak Journal of Food Sciences, 13 (1), 449-455. https://doi. org/10.5219/1109 (in Ukrainian).

16. Frolova, N.E., Chepel, N.V., Naumenko, K.A. and Usatyuk E.M. 2013. Study of the isolation of aromatic components of essential oils by preparative chromatography. Scientific journal $\mathrm{SPb}$ NIUITMO. Saint Petersburg: SPb. NIUITMO. 1 (in Russian). URI: http://dspace.nuft.edu.ua/jspui/ handle/123456789/7696

17. Frolova, N.E. and Usatyuk, E.M. 2014. Development of techniques for capillary chromatography of terpene hydrocarbons and oxygenated of essential oils. Eastern European Journal of Advanced Technologies, 5 (11/71), 57-62. URL: http://nbuv.gov. ua/UJRN/Vejpte_2014_5(11)_13.

18. Gindullina T.M. and Dubova N.M. 2010. Chromatographic methods of analysis: a textbook. Publishing house of Tomsk polytechnic university (in Russian). URL: https://portal.tpu.ru/SHARED/o/OAA/ 
academic/Tab2/Chromatography_posobie.pdf

19. Gupta M.K. 2002. Sunflower oil. Vegetable oils in food technology. In: Vegetable Oils in Food Technology Composition, Properties and Uses, (Ed. Gunstone F.D.). Blackwell Publishing: Oxford. 128-156.

20. Kovalenko N.A., Supichenko G.N., Leontiev V.N., Shutova A.G. and Klyuchnik O.K. 2009. Identification and determination of optically active components of essential oil Coriandrum sativum L. Proceedings of the Belarusian state technological university. Series 4: chemistry, organic technology and biotechnology, 1 (4), 123-135 (in Russian). URL: https://cyberleninka.ru/article/n/identifikatsiya-i-opredelenie-opticheski-aktivnyh-komponento v-efirnogo-masla-c-oriandrum-sativum-1-1/viewer

21. Kondratyuk T.A. and Zykova I.D. 2013. Essential oils of spice plants. The successes of modern natural science, 9, 135-139 (in Russian. URL: URL: http:// www.natural-sciences.ru/ru/article/view? $\mathrm{id}=32898$

22. Korablova O.A. and Rakhmetov D.B. 2012. Useful plants in Ukraine: From introduction to use. Kiev: Phytosociocenter (in Russian).

23. Lawrence B.M. 2009. A preliminary report on the world production of some selected essential oils and countries. Perfumer \& Flavorist, 34 (1), 38-44. URL: https://media.allured.com/documents/ PF_34_01_038_07.pdf

24. Lorenzo J.M., Munekata P.E.S., Baldin J.C., Franco D., Domínguez R. and Trindade M.A. 2017. The use of natural antioxidants to replace chemical antioxidants in foods. Strategies for obtaining healthier foods; Nova Science Publishers, Inc.: New York, USA. 205-228.

25. MisharinaT.A., Terenina M.B., Krikunova N.I. andKalinichenko M.A. 2010. Influence of the composition of lemon essential oils on their antioxidant properties and component stability. Chemistry of plant raw materials, 1,87-92 (in Russian). https://cyberleninka.ru/article/n/ vliyanie-sostava-efirnyh-masel-limona-na-ih-antioksidantnye-svoystva-i-stabilnost-komponentov/ viewer

26. Modzelewska A., Sur S., Kumar S.K. and Khan S.R. 2005. Sesquiterpenes: Natural products that decrease cancer growth. Curr. Med.Chem. Anti-cancer Agents, 5 (5), 477-499. https://doi. org/10.2174/1568011054866973

27. Munekata P.E.S., Gullón B., Pateiro M., Tomasevic I., Domínguez R. and Lorenzo J.M. 2020. Natural antioxidants from seeds and their application in meat roducts. Antioxidants, 9 (9), 815-825. https:// doi.org/10.3390/antiox9090815
28. Nahas R.I. 2012. Natural antioxidants as food and beverage ingredients. Natural Food Additives, Ingredients and Flavourings. Woodhead Publishing: Sawston/Cambridge, UK, 100-126.

29. Oswell N.J., Thippareddi H. and Pegg R.B. 2018. Practical use of natural antioxidants in meat products in the U.S.: A review. Meat Sci, 145, 469-479. https://doi.org/10.1016/j.meatsci.2018.07.020

30. Ponomareva E.I., Molokhova E.I. and Kholov A.K. 2015. Using of essential oils in pharmacy. Modern problems of science and education, 4, 1-8 (in Russian). URL: http://www.science-education.ru/ru/ article/view?id=21156

31. Rabotyagov V.D, Khlypenko L.A., Svidenko L.V. and Logvinenko I.E. 2011. New varieties of aromatic and medicinal plants breeding by Nikitsky Botanical Garden. Proceedings of the Nikitsky Botanical Garden, 133, 5-17 (in Russian). http:// scbook.nbgnsc.ru/download/133/133.pdf

32. Samusenko A.L. 2011. Investigation of the antioxidant activity of essential oils of lemon, pink grapefruit, coriander, clove and their mixtures by capillary gas chromatography. Chemistry of plant raw materials, 3, 107-112 (in Russian). https://cyberleninka.ru/ article/n/issledovanie-antioksidantnoy-aktivnostiefirnyh-masel-limona-rozovogo-greypfruta-koriandra-gvozdiki-i-ih-smesey-metodom-kapillyarnoy/ viewer

33. SStU 4653: 2006. Essential oil from dill. Specifications. (State Standard of Ukraine) (in Ukrainian).

34. SStU ISO 3033-2002. Essential oil of mint (Mentha spicata Linnaeus). (State Standard of Ukraine) (in Ukrainian).

35. SStU ISO 6886-2003. Animal and vegetable fats and oils. Determination of resistance to oxidation. Accelerated oxidation test. (State Standard of Ukraine) (in Ukrainian).

36. Sizova, N.V. 2012. Composition and antioxidant activity of essential oils containing azulene derivatives. Pharmaceutical Chemistry Journal, 46 (6), 42-44 (in Russian).

37. Tolba K.H., Youssef S.M. and Abd-Elwahab E.S. 2008. Physicochemical properties and its application of dill (Anethum graveolens) and parsley (Petroselinum sativum) and their essential oils. Arab Univ. J. Agric. Sci, 16 (2), 379-387. DOI: 10.21608/ AJS.2008.14953

38. Wagner G. 1894. Zur oxidation cyklischer Verbindungen. (On the oxidation of cyclic compounds). Berichte der Deutschen chemischen Gesellschaft zu Berlin, 27, 2270-2276. URL: https://gallica.bnf.fr/ ark:/12148/bpt6k90735d/f492.image.langEN 